\title{
Environmental Impact Assessment and Prevention Measures by Example PJSC "Gazprom"
}

\author{
Denis Khulukshinov ${ }^{1, *}$ \\ ${ }^{1}$ Scientific Research Institute of Natural Gases and Gas Technologies - Gazprom VNIIGAZ LLC, \\ 142717 Proektiruemyj proezd № 5537, vladenie 15, stroenie 1, Moskovskaya oblast, Russian \\ Federation
}

\begin{abstract}
PJSC Gazprom carries out large-scale production activities following the principles of sustainable development and environmental preservation. The development of gasification and the transfer of transport to methane make a significant contribution to the improvement of the ecological situation in the constituent entities of the Russian Federation and the implementation of the federal project "Clean Air". In 2019, the Comprehensive Environmental Program for 2020-2024 was developed and approved, it provides for a system of measures that corresponds to state objectives for the innovative environmental development of the Russian economy.
\end{abstract}

\section{Introduction}

During the project implementation PJSC Gazprom takes into account a balanced combination of economic growth and environmental protection. Since 2011, a certified EMS has been operating, which is aimed at implementing environmental policy, managing the environmental aspects of PJSC Gazprom's activities, setting and achieving environmental goals [1].

In order to further improve the corporate governance system in the field of environmental protection, energy efficiency and sustainable development, PJSC Gazprom has a Coordinating Committee for Environmental Management. To improve the efficiency of managerial decision-making, PJSC Gazprom has implemented a list of programs that covers the entire chain of environmental protection activities in Gazprom Group companies, from data collection and processing to the generation of consolidated reports. Since 2019, the environmental management information and control system has been put into commercial operation in the subsidiaries of PJSC Gazprom for the production, transportation, underground storage and processing of gas, which allows monitoring key performance indicators in the field of environmental protection.

\footnotetext{
* Corresponding author: denis.rudn@gmail.com
} 


\section{Materials and methods}

The purpose of the article is to analyze the impact on the environment, determine the main directions of financing, target indicators, as well as an assessment methodology based on the criteria for the significance of the impact.

The main idea is to assess the environment at the local, limited, local and regional level of impact, as well as taking into account the spatial and temporal scale, intensity.

The role of the author is to organize and analyze the data, identify priority segments for funding and cost effectiveness, the proposed environmental impact assessment.

In preparing the materials, the works of domestic scientists in the field of environmental impact assessment and environmental support of projects were used, data of annual statistical reports in the field of environmental protection and energy efficiency of PJSC Gazprom for 2015-2019 were used, which are accumulated by the corporate information and management system, as well as other materials contained in the reports on environmental activities, on corporate Internet resources, in the publications of the Group companies Gazprom in Russian and foreign publications [2-9].

The article reflects information on PJSC Gazprom's activities in the field of environmental protection, including indicators of impact on the atmospheric air, water and land resources, waste management and measures to reduce such impact.

It also covers the issues of organizing management and financing of environmental protection, scientific research and modernization of industrial complexes aimed at improving the environmental safety of PJSC Gazprom's facilities.

The indicators are given including a retrospective for 5 years as a whole for PJSC Gazprom, as well as for individual companies of the Gazprom Group that make a significant contribution to the above areas of activity.

\section{Results and discussion}

Assessment of possible environmental impacts resulting from the implementation of the project is an important stage in the process of environmental impact assessment (hereinafter - EIA). The general scheme for the EIA is as follows (Fig. 1).

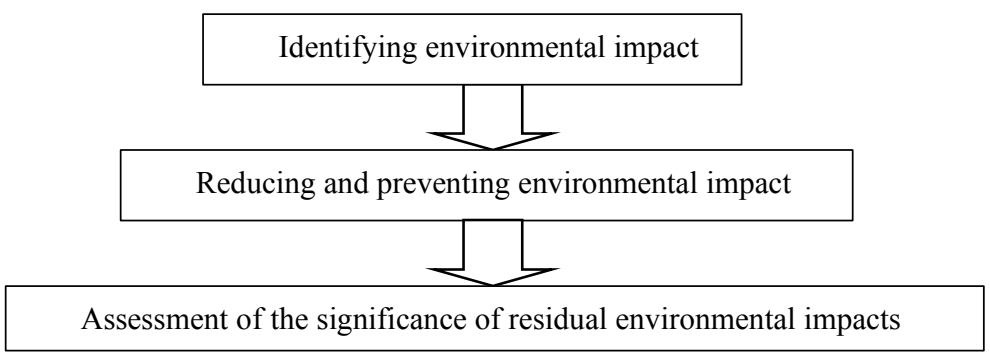

Fig. 1. Environmental impact assessment.

The purpose of the EIA is to determine the environmental changes that may arise in the course of the activity and to assess the significance of these changes. This estimate is based on [4-9]:

- technical description of the project;

- identification of environmental components that are confirmed to be affected;

- experience gained from other projects.

EIA is carried out for individual components of the environment the following can be distinguished as the most important ecosystems and components [4-9]: 
- mail and subsoil;

- surface and sea waters;

- the groundwater;

- marine sediments;

- air quality;

- biological resources;

- landscapes and spectator impact;

Measures and activities that are taken to mitigate the impact on the environment are established during the development of the project (Table 1) [4-9].

Table 1. Structure of measures to reduce and prevent environmental impacts.

\begin{tabular}{|c|c|}
\hline Name & Description \\
\hline $\begin{array}{l}\text { Prevention / } \\
\text { reduction at source }\end{array}$ & $\begin{array}{l}\text { Design solutions are applied that exclude or modify the } \\
\text { cause of the impact }\end{array}$ \\
\hline Reduction in place & $\begin{array}{c}\text { Various modifications are applied to the original design } \\
\text { development }\end{array}$ \\
\hline $\begin{array}{l}\text { Attenuation at the } \\
\text { receptor }\end{array}$ & $\begin{array}{l}\text { If it is impossible to mitigate the impact at the discharge } \\
\text { site, it is proposed to carry out these measures outside the } \\
\text { site of the facility }\end{array}$ \\
\hline Repair or fix & $\begin{array}{l}\text { During the implementation of projects, a negative impact on } \\
\text { natural resources is carried out. Recovery involves measures } \\
\text { to prevent the resource from returning to its original state }\end{array}$ \\
\hline $\begin{array}{l}\text { Compensation by } \\
\text { reimbursement }\end{array}$ & $\begin{array}{l}\text { In the event that mitigation measures are impossible or } \\
\text { insufficiently effective, it is proposed to use compensation } \\
\text { for losses and damage }\end{array}$ \\
\hline
\end{tabular}

EIA is proposed to be carried out at local, limited, local and regional level of environmental impact (Table 2).

Table 2. Gradation of environmental impact.

\begin{tabular}{|c|c|c|}
\hline Name & Description \\
\hline Local impact & $\begin{array}{c}\text { This is an impact that affects the components of the natural } \\
\text { environment, limited by the territory (water area) of the } \\
\text { immediate location of the object or slightly exceeding it in } \\
\text { area (up to } 1 \mathrm{~km}^{2} \text { ), affecting the elementary natural- } \\
\text { territorial complexes on land at the level of facies or tracts }\end{array}$ \\
\hline Limited impact & $\begin{array}{c}\text { This is an impact in which there is an impact on the } \\
\text { components of the natural environment in the territory } \\
\text { (water area) up to } 10 \mathrm{~km}^{2} \text {, affecting the natural-territorial } \\
\text { complexes on land at the level of groups of natural } \\
\text { boundaries or terrain }\end{array}$ \\
\hline Local (territorial) & $\begin{array}{c}\text { This is the impact that affects the components of the natural } \\
\text { environment in the territory (water area) up to 100 km }{ }^{2}, \\
\text { affecting the natural-territorial complexes on land at the } \\
\text { landscape level }\end{array}$ \\
\hline Regional impact & $\begin{array}{c}\text { This is an impact that affects the components of the natural } \\
\text { environment on a regional scale in the territory (water area) } \\
\text { of more than } 100 \mathrm{~km}^{2} \text {, affecting the natural-territorial } \\
\text { complexes on land at the level of landscape districts or } \\
\text { provinces }\end{array}$ \\
\hline
\end{tabular}

These levels are proposed to be assessed according to the following parameters:

- spatial scale;

- time scale;

- intensity. 
When assessing an EIA, it becomes difficult to quantify environmental changes. Therefore, the proposed methodology is based on a semi-quantitative assessment with the assignment of points (Table 3).

Table 3. Determination of spatial and temporal impact, as well as intensity of impact on the environment.

\begin{tabular}{|c|c|c|c|}
\hline \multicolumn{4}{|c|}{ Scale for assessing the spatial scale (area) environmental impact } \\
\hline Gradation & \multicolumn{2}{|c|}{ Spatial boundaries of impact } & Score \\
\hline Local impact & $\begin{array}{l}\text { Impact area up to } 1 \\
\mathrm{~km}^{2}\end{array}$ & $\begin{array}{l}\text { Impact at a distance of } \\
\text { up to } 100 \mathrm{~m} \text { from a } \\
\text { linear object }\end{array}$ & 1 \\
\hline Limited impact & $\begin{array}{l}\text { Impact area up to } 10 \\
\mathrm{~km}^{2}\end{array}$ & $\begin{array}{l}\text { Impact at a distance of } \\
\text { up to } 1 \mathrm{~km} \text { from the } \\
\text { linear object }\end{array}$ & 2 \\
\hline $\begin{array}{l}\text { Local } \\
\text { (territorial) } \\
\text { impact }\end{array}$ & $\begin{array}{l}\text { Impact area from } 10 \\
\mathrm{~km}^{2} \text { to } 100 \mathrm{~km}^{2}\end{array}$ & $\begin{array}{l}\text { Impact at a distance of } \\
1 \text { to } 10 \mathrm{~km} \text { from the } \\
\text { linear object }\end{array}$ & 3 \\
\hline Regional impact & $\begin{array}{l}\text { Impact area more than } \\
100 \mathrm{~km}^{2}\end{array}$ & $\begin{array}{l}\text { Impact at a distance of } \\
\text { more than } 10 \mathrm{~km} \text { from } \\
\text { the linear object }\end{array}$ & 4 \\
\hline \multicolumn{4}{|c|}{$\begin{array}{l}\text { Note: Determination of the spatial scale of environmental impact is carried out on } \\
\text { the analysis of technical solutions, mathematical modeling, or on the basis of expert } \\
\text { assessments. }\end{array}$} \\
\hline \multicolumn{4}{|c|}{ Temporary Environmental Impact Assessment Scale } \\
\hline $\begin{array}{l}\text { Short-term } \\
\text { exposure }\end{array}$ & \multicolumn{2}{|c|}{ Exposure lasts up to 3 months } & 1 \\
\hline $\begin{array}{l}\text { Medium } \\
\text { duration } \\
\text { exposure }\end{array}$ & \multicolumn{2}{|c|}{ Exposure lasts from 3 months to 1 year } & 2 \\
\hline $\begin{array}{l}\text { Long-term } \\
\text { exposure }\end{array}$ & \multicolumn{2}{|c|}{ Exposure lasts from 1 to 3 years } & 3 \\
\hline $\begin{array}{l}\text { Long-term } \\
\text { (permanent) } \\
\text { exposure }\end{array}$ & \multicolumn{2}{|c|}{$\begin{array}{c}\text { Exposure has been observed for } 3 \text { to } 5 \text { years and } \\
\text { more than }\end{array}$} & 4 \\
\hline \multicolumn{4}{|c|}{$\begin{array}{l}\text { Note: Determination of temporary large-scale environmental impact on individual } \\
\text { components of the natural environment is determined on the basis of technical } \\
\text { analysis, analytical (model) assessments or expert assessments. }\end{array}$} \\
\hline \multicolumn{4}{|c|}{ The scale of the magnitude of the intensity of impact on the environment } \\
\hline Minor impact & \multicolumn{2}{|c|}{$\begin{array}{l}\text { Changes in the environment do not exceed the } \\
\text { existing limits of natural variability }\end{array}$} & 1 \\
\hline Weak impact & \multicolumn{2}{|c|}{$\begin{array}{l}\text { Changes in the environment exceed the limits of } \\
\text { natural variability. The natural environment is } \\
\text { completely self-healing }\end{array}$} & 2 \\
\hline $\begin{array}{l}\text { Moderate } \\
\text { impact }\end{array}$ & \multicolumn{2}{|c|}{$\begin{array}{l}\text { Changes in the environment that exceed the } \\
\text { limits of natural variability lead to a violation of } \\
\text { individual components of the natural } \\
\text { environment. The natural environment retains the } \\
\text { ability to heal itself }\end{array}$} & 3 \\
\hline Strong impact & \multicolumn{2}{|c|}{$\begin{array}{l}\text { Changes in the environment lead to significant } \\
\text { disruptions to components of the natural } \\
\text { environment and / or ecosystems. Individual } \\
\text { components of the natural environment lose their } \\
\text { ability to heal themselves }\end{array}$} & 4 \\
\hline
\end{tabular}


The calculation of a comprehensive (integral) assessment of the impact on individual components of the environment, depending on various sources of impact, is given by the formula:

$$
\mathrm{Q}^{\mathrm{i}}{ }_{\text {integr }}=\mathrm{Q}_{\mathrm{i}}^{\mathrm{t}} \times \mathrm{Q}_{\mathrm{i}}^{\mathrm{s}} \times \mathrm{Q}_{\mathrm{i}}^{\mathrm{j}}
$$

$\mathrm{Q}_{\text {integr }} \mathrm{i}_{\mathrm{i}}$ a comprehensive rating score for a given environmental impact;

$\mathrm{Q}_{\mathrm{i}}^{\mathrm{t}}$ - point of temporary impact on the $\mathrm{i}$-th component of the environment;

$\mathrm{Q}_{\mathrm{i}}^{\mathrm{s}}$ - the point of the spatial impact on the $\mathrm{i}$-th component of the environment;

$\mathrm{Q}_{\mathrm{i}}^{\mathrm{i}}$ - score of the intensity of impact on the $\mathrm{i}$-th component of the environment.

The significance category is determined by the range of values depending on the score obtained when calculating the complex assessment (Table 4).

Table 4. Environmental Impact Significance Categories.

\begin{tabular}{|c|c|c|c|}
\hline \multicolumn{3}{|c|}{ Impact categories, score } & \multirow{2}{*}{$\begin{array}{l}\text { Integral } \\
\text { assessment, } \\
\text { score }\end{array}$} \\
\hline Spatial scale & Time scale & Impact intensity & \\
\hline $\begin{array}{c}\text { Local } \\
1\end{array}$ & $\begin{array}{c}\text { Short-term } \\
1\end{array}$ & $\begin{array}{c}\text { Minor } \\
1\end{array}$ & 1 \\
\hline $\begin{array}{l}\text { Limited } \\
2\end{array}$ & $\begin{array}{l}\text { Average duration } \\
2\end{array}$ & $\begin{array}{c}\text { Weak } \\
2\end{array}$ & 8 \\
\hline $\begin{array}{l}\text { Local (territorial) } \\
3\end{array}$ & $\begin{array}{c}\text { Long lasting } \\
3\end{array}$ & $\begin{array}{l}\text { Moderate } \\
3\end{array}$ & 27 \\
\hline $\begin{array}{c}\text { Regional } \\
4\end{array}$ & $\begin{array}{l}\text { Perennial (permanent) } \\
4\end{array}$ & $\begin{array}{c}\text { Strong } \\
4\end{array}$ & 64 \\
\hline \multicolumn{4}{|c|}{$\begin{array}{l}\text { Scores 1-8 - Impact of low significance. } \\
\text { Scores 9-27 - Impact of medium significance. } \\
\text { Scores 28-64 - Impact of high significance. }\end{array}$} \\
\hline \multicolumn{4}{|c|}{$\begin{array}{l}\text { Note: } \\
\text { 1. Impact of low significance occurs when the effects are experienced, but the magnitude of the } \\
\text { impact is low enough, and also within acceptable standards, or the receptors have low sensitivity } \\
\text { / value. } \\
\text { 2. Impacts of moderate significance can have a wide range, ranging from a threshold below } \\
\text { which the impact is low, to a level that almost violates the legal limit. Whenever possible, it } \\
\text { should be shown that the impact is of moderate significance. } \\
\text { 3. Impacts of high significance occur when tolerance limits are exceeded or when large scale } \\
\text { impacts are noted, especially with respect to valuable / sensitive resources. }\end{array}$} \\
\hline
\end{tabular}

This EIA methodology can be applied at various levels, including at PJSC Gazprom.

At present PJSC Gazprom approved the Corporate Environmental Goals for 2020-2022, with the aim of coordinating and monitoring their implementation, the Comprehensive Environmental Program for 2020-2024 was approved (Table 5) [10].

Table 5. Target indicators of the comprehensive environmental program of PJSC Gazprom for 20202024.

\begin{tabular}{|c|c|c|c|c|}
\hline Indicator name & $\begin{array}{c}\text { Unit } \\
\text { measurements }\end{array}$ & $\begin{array}{c}\text { Basic } \\
\text { level } \\
(2018)\end{array}$ & $\begin{array}{c}\text { Target } \\
(2024)\end{array}$ & $\begin{array}{c}\text { Numerical } \\
\text { value }\end{array}$ \\
\hline $\begin{array}{c}\text { Reducing greenhouse gas emissions } \\
\text { from natural gas transportation }\end{array}$ & $\begin{array}{c}\mathrm{t} \mathrm{CO} \text { eq. / } \\
\text { billion } \mathrm{m}^{3} \\
\mathrm{~km}\end{array}$ & 55,3 & $\begin{array}{c}\text { Down } \\
3,8 \%\end{array}$ & $\begin{array}{c}\text { Down to } \\
53.2\end{array}$ \\
\hline $\begin{array}{c}\text { Reducing emissions of nitrogen } \\
\text { oxides into the air during } \\
\text { transportation of natural gas }\end{array}$ & $\mathrm{t} / \mathrm{mln} \mathrm{m}^{3}$ & 4,23 & $\begin{array}{c}\text { Down } \\
5,0 \%\end{array}$ & $\begin{array}{c}\text { Down to } \\
4,0\end{array}$ \\
\hline
\end{tabular}




\begin{tabular}{|c|c|c|c|c|}
\hline $\begin{array}{c}\text { Decrease in the proportion of excess } \\
\text { discharge and surface water bodies } \\
\text { from the total mass of 3B in the } \\
\text { diverted waters }\end{array}$ & $\%$ & 5,29 & $\begin{array}{c}\text { Down } \\
1,3 \%\end{array}$ & $\begin{array}{c}\text { Down to } \\
4,0\end{array}$ \\
\hline $\begin{array}{c}\text { Reducing the share of waste to be } \\
\text { buried in the total mass of waste in } \\
\text { circulation }\end{array}$ & $\%$ & 38,28 & $\begin{array}{c}\text { Down } \\
5,8 \%\end{array}$ & $\begin{array}{c}\text { Down to } \\
32,45\end{array}$ \\
\hline $\begin{array}{c}\text { Decrease in the share of subsidiaries } \\
\text { exceeding } 5 \% \text { of the level of payment } \\
\text { for excess of the normative impact on } \\
\text { the environment }\end{array}$ & $\%$ & 35 & $\begin{array}{c}\text { Down } \\
8,6 \%\end{array}$ & $\begin{array}{c}\text { Down to } \\
26,5\end{array}$ \\
\hline
\end{tabular}

The program is aimed at improving the efficiency of environmental protection management and rational use of natural resources through organizational and technological measures, as well as research and development work, taking into account new environmental challenges and the state's course towards innovative environmental development.

The reduction of target indicators by 2024 is defined in the range of $1-8 \%$, the indicators of 2018 are taken as the base level.

Financing of Gazprom Group companies for environmental protection for the period from 2015 to 2019 is presented in Table 6 (hereinafter based on Environmental reports of PJSC Gazprom).

Table 6. Dynamics of expenditures of Gazprom Group companies on environmental protection in 2015-2019, billion rubles.

\begin{tabular}{|c|c|c|c|c|c|}
\hline Year & 2015 & 2016 & 2017 & 2018 & 2019 \\
\hline $\begin{array}{c}\text { Environmental protection } \\
\text { costs }\end{array}$ & 49,71 & 57,47 & 70,82 & 68,96 & 53,22 \\
\hline
\end{tabular}

In 2019 , it amounted to 53.22 billion rubles, which is $22.8 \%$ less compared to 2018 . This decrease is due to the completion of a large number of investment projects.

Investments in fixed assets aimed at environmental protection in 2019 amounted to 20.42 billion rubles, in general for the period from 2015 to 2019. Gazprom Group companies invested about 123.5 billion rubles. (Table 7).

Table 7. Dynamics of investments in fixed assets aimed at environmental protection and rational use of natural resources in 2015-2019, billion rubles.

\begin{tabular}{|c|c|c|c|c|c|}
\hline Name & 2015 & 2016 & 2017 & 2018 & 2019 \\
\hline $\begin{array}{c}\text { Gazprom Group } \\
\text { companies }\end{array}$ & 15,75 & 22,54 & 35,58 & 29,19 & 20,42 \\
\hline $\begin{array}{c}\text { Gas business } \\
\text { companies }\end{array}$ & 6,93 & 2,54 & 4,45 & 5,61 & 5,73 \\
\hline $\begin{array}{c}\text { including PJSC } \\
\text { "Gazprom" }\end{array}$ & 6,89 & 2,27 & 2,86 & 5,28 & 5,12 \\
\hline Gazprom Neft Group & 3,11 & 14,27 & 27,10 & 19,03 & 13,01 \\
\hline $\begin{array}{c}\text { Gazprom } \\
\text { energoholding }\end{array}$ & 2,84 & 0,37 & 0,58 & 1,38 & 0,31 \\
\hline $\begin{array}{c}\text { Gazprom neftekhim } \\
\text { Salavat }\end{array}$ & 2,87 & 5,36 & 3,45 & 3,17 & 1,37 \\
\hline
\end{tabular}

Financing of large investment projects for the construction of the main gas pipelines Power of Siberia, Nord Stream 2, and Turkish Stream continues. In 2019, investments were distributed as follows (Fig. 2) [10]:

- $\quad$ protection of atmospheric air in the amount of 10.18 billion rubles $(50 \%)$; 
- $\quad$ protection and rational use of water resources in the amount of 6.44 billion rubles $(31 \%)$;

- $\quad$ protection and rational use of land in the amount of 2.39 billion rubles (12\%);

- solution of other tasks in the field of environmental protection in the amount of 1.41 billion rubles $(7 \%)$.

Operating expenses of Gazprom Group companies for environmental protection in 2019 amounted to 32.18 billion rubles (Table 8 ).

Table 8. Dynamics of current expenses for environmental protection in 2015-2019, billion rubles.

\begin{tabular}{|c|c|c|c|c|c|}
\hline Name & 2015 & 2016 & 2017 & 2018 & 2019 \\
\hline $\begin{array}{c}\text { Gazprom Group } \\
\text { companies }\end{array}$ & 32,17 & 34,10 & 34,47 & 39,15 & 32,18 \\
\hline $\begin{array}{c}\text { Gas business } \\
\text { companies }\end{array}$ & 17,35 & 18,76 & 19,25 & 21,12 & 19,91 \\
\hline $\begin{array}{c}\text { including PJSC } \\
\text { "Gazprom" }\end{array}$ & 14,79 & 15,42 & 15,59 & 16,14 & 16,30 \\
\hline Gazprom Neft Group & 6,66 & 7,00 & 7,03 & 6,08 & 8,05 \\
\hline $\begin{array}{c}\text { Gazprom } \\
\text { energoholding }\end{array}$ & 2,21 & 2,72 & 2,32 & 2,13 & 2,49 \\
\hline $\begin{array}{c}\text { Gazprom neftekhim } \\
\text { Salavat }\end{array}$ & 5,95 & 5,62 & 5,87 & 9,82 & 1,73 \\
\hline
\end{tabular}

The cost structure of Gazprom Group companies is (Fig. 2) [10]:

- collection and treatment of waste water in the amount of 13.03 billion rubles (40\%);

- $\quad$ protection and rehabilitation of land in the amount of 6.68 billion rubles $(21 \%)$;

- waste management in the amount of 5.69 billion rubles $(18 \%)$;

- protection of atmospheric air and prevention of climate change in the amount of 4.48 billion rubles $(14 \%)$;

- other activities in the field of environmental protection in the amount of 1.95 billion rubles $(6 \%)$;

- $\quad$ preservation of biodiversity and protection of natural areas in the amount of 0.35 billion rubles $(1 \%)$.

\begin{tabular}{|c|c|c|c|}
\hline $12 \% 7 \%$ & $\begin{array}{l}\text { - Atmospheric } \\
\text { air protection } \\
\text { - Protection and } \\
\text { rational use of } \\
\text { water } \\
\text { resources } \\
\text { - Protection and } \\
\text { rational use of } \\
\text { land } \\
\text { - Other tasks in } \\
\text { the field of } \\
\text { environmental } \\
\text { protection }\end{array}$ & 21\% & $\begin{array}{l}\text { - Collection and treatment of } \\
\text { waste water } \\
\text { - Land protection and } \\
\text { rehabilitation } \\
\text { - Waste management } \\
\text { - Air protection and climate } \\
\text { change prevention } \\
\text { - Other activities in the field } \\
\text { of environmental protection } \\
\text { - Conservation of } \\
\text { biodiversity and protection } \\
\text { of natural areas }\end{array}$ \\
\hline
\end{tabular}

Fig. 2. Structure of investments (left) and current costs (right) of Gazprom Group companies for environmental protection in $2019, \%$. 
As part of its production activities, PJSC Gazprom pays for the negative impact on the environment to the budgets of various levels (Table 9).

Table 9. Payments for the negative impact on the environment of the Gazprom Group companies for 2015-2019, billion rubles.

\begin{tabular}{|c|c|c|c|c|c|}
\hline Year & 2015 & 2016 & 2017 & 2018 & 2019 \\
\hline Gazprom Group companies & 1,79 & 0,82 & 0,76 & 0,61 & 0,62 \\
\hline
\end{tabular}

For the period 2015-2019 PJSC Gazprom was paid 4.6 billion rubles for the negative impact on the environment to the budgets of the constituent entities of the Russian Federation, including 0.62 billion rubles in 2019 , of which $52 \%$ were payments for emissions of pollutants (3B) into the air and $45 \%$ for waste disposal. This indicator has decreased by 3 times compared to 2015 .

\subsection{Impact on atmospheric air}

Gross emissions of 3B into the air from stationary sources of PJSC Gazprom for 5 years amounted to 14251.72 thousand tons, including 2862.70 thousand tons in 2019, which is 31.32 thousand tons less compared to 2018 (Fig. 3).

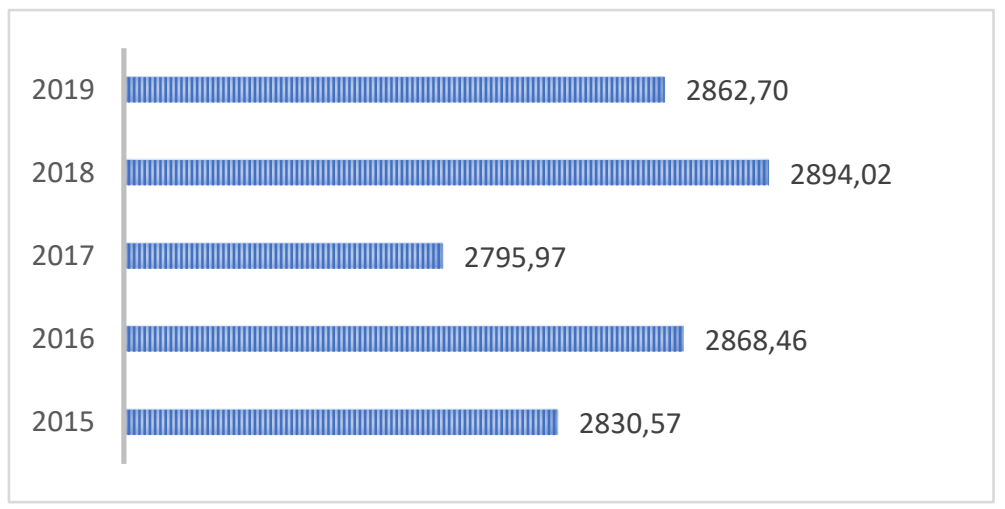

Fig. 3. Dynamics of gross emissions of 3B into the atmosphere by Gazprom Group companies for 2015-2019, thousand tons.

With the help of cleaning plants 1473.88 thousand tons of harmful emissions were neutralized. Their structure is determined by the specifics of the activity PJSC Gazprom and other companies in the gas sector (Table 10) [10].

Table 10. Component structure of air emissions in Gazprom Group companies in 2019, thousand tons.

\begin{tabular}{|c|c|c|}
\hline Name & $\begin{array}{c}\text { Gazprom Group } \\
\text { companies }\end{array}$ & Gas companies \\
\hline Hydrocarbons (including methane) & 1542,64 & 1478,94 \\
\hline Hydrocarbon oxide & 596,42 & 365,70 \\
\hline Nitric oxide & 307,71 & 184,13 \\
\hline sulphur dioxide & 221,46 & 59,48 \\
\hline Volatile organic compounds & 124,76 & 26,40 \\
\hline Solids & 67,47 & 3,78 \\
\hline Other gaseous and liquid substances & 2,24 & 0,86 \\
\hline
\end{tabular}


The main share in emissions is taken by hydrocarbons (54\%), emissions of solid substances are typical for the energy segment of PJSC Gazprom, emissions of volatile organic compounds for companies in the gas sector and the Gazprom Neft group.

In order to reduce 3B emissions into the air, Gazprom Group companies are taking various environmental measures. For example, gas production companies conduct technological studies of wells without releasing natural gas into the atmosphere and use multicomponent compositions of surfactants; gas transmission subsidiaries use pressure injection technologies, as well as technologies for pumping natural gas using compressor units.

\subsection{Water resources}

In the field of water use, PJSC Gazprom reduces the negative impact by reducing water consumption for production needs and reducing wastewater discharge into surface water bodies.

For the period 2015-2019 Gazprom Group companies took (received) 21775.09 million $\mathrm{m}^{3}$ for water supply purposes, including 3921.41 million $\mathrm{m}^{3}$ in 2019 , of which 3571.28 million $\mathrm{m}^{3}(91 \%)$ from natural sources (Table 11$)$.

Table 11. Water use indicators by Gazprom Group companies for 2015-2019, $\mathrm{mln} \mathrm{m}^{3}$.

\begin{tabular}{|c|c|c|c|c|c|}
\hline Name & 2015 & 2016 & 2017 & 2018 & 2019 \\
\hline $\begin{array}{c}\text { Collected, received } \\
\text { water }\end{array}$ & 4511,81 & 4538,21 & 4523,45 & 4280,21 & 3921,41 \\
\hline $\begin{array}{c}\text { including from natural } \\
\text { sources }\end{array}$ & 4290,12 & 4301,46 & 4283,52 & 4065,34 & 3571,28 \\
\hline Used for own needs & 4387,64 & 4449,27 & 4421,11 & 4180,89 & 3863,11 \\
\hline $\begin{array}{c}\text { including production } \\
\text { needs }\end{array}$ & 4149,04 & 4192,10 & 4164,84 & 3947,36 & 3678,12 \\
\hline $\begin{array}{c}\text { Drainage to surface } \\
\text { water bodies }\end{array}$ & 3853,75 & 3855,45 & 3905,26 & 3658,44 & 3241,79 \\
\hline
\end{tabular}

Over 5 years, the companies of the Gazprom Group have reduced water consumption for production needs by $11 \%$, and water intake from natural sources by $17 \%$. In 2019,145 wastewater treatment plants with a total capacity of 26.66 thousand $\mathrm{m}^{3} /$ day were commissioned [10].

PJSC Gazprom is taking environmental measures aimed at increasing the efficiency of water use in production activities and the degree of purification of discharged wastewater.

\subsection{Land resources}

As part of the of geological exploration and construction works, as well as during the operation of wells and pipelines, the vegetation and soil cover is affected.

For the period 2015-2019 Gazprom Group companies disturbed lands with an area of 175.92 thousand hectares, of which 113.71 thousand hectares were reclaimed (Fig. 4). 


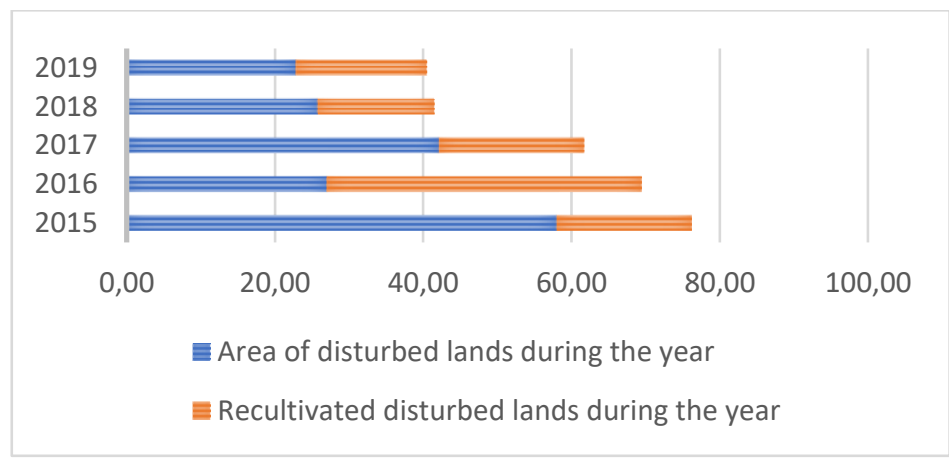

Fig. 4. Performance indicators in the field of land protection in the Gazprom Group companies for 2015-2019, thousand hectares.

In 2019, 22.89 thousand hectares of land were disturbed, which is $11 \%$ less than in 2018 , of which 17.67 thousand hectares of land (77\%) were reclaimed. The largest share falls on PJSC Gazprom 12.72 thousand hectares, Gazprom Neft Group 8.46 thousand hectares and other companies of the Group 1.71 thousand hectares [10].

To restore the disturbed lands, PJSC Gazprom carries out work on technical and biological reclamation, which allows restoring the productivity and economic value of disturbed lands, as well as preserving landscapes. In addition, measures are being taken to improve the reliability of pipeline systems in order to have a positive impact on the preservation of the components of the natural environment.

\subsection{Waste management}

For the period 2015-2019 Gazprom Group companies generated 20266.32 thousand tons of waste, including 3337.08 thousand tons in 2019. Over 5 years, the volume of waste generated by PJSC Gazprom decreased by $33 \%$ (Fig. 5).

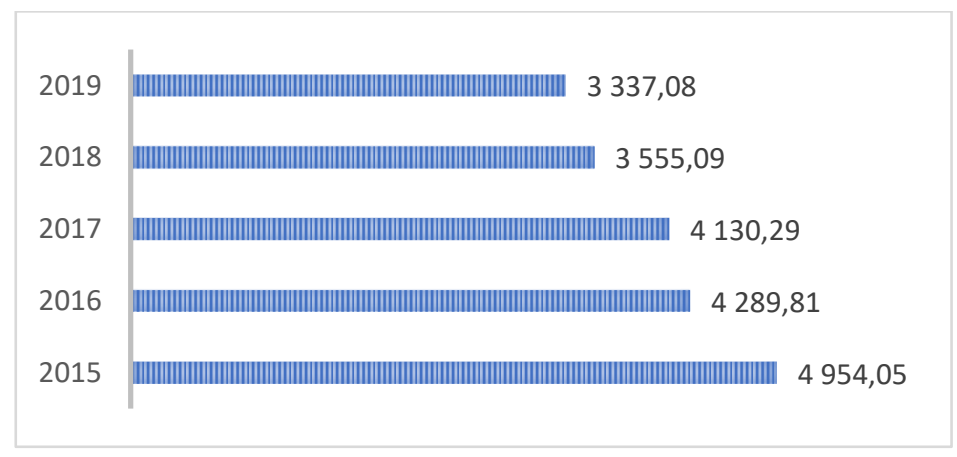

Fig. 5. Dynamics of waste generation by Gazprom Group companies in 2015-2019, thousand tons.

The positive dynamics in terms of waste reduction is due to the replacement of coal with natural gas, the largest part of production waste (95\%) of the Gazprom Group companies is classified as low-hazard or practically non-hazardous.

The waste structure contains ash and slag waste, drilling waste, oil sludge, as well as other types of waste (Fig. 6) [10]. 


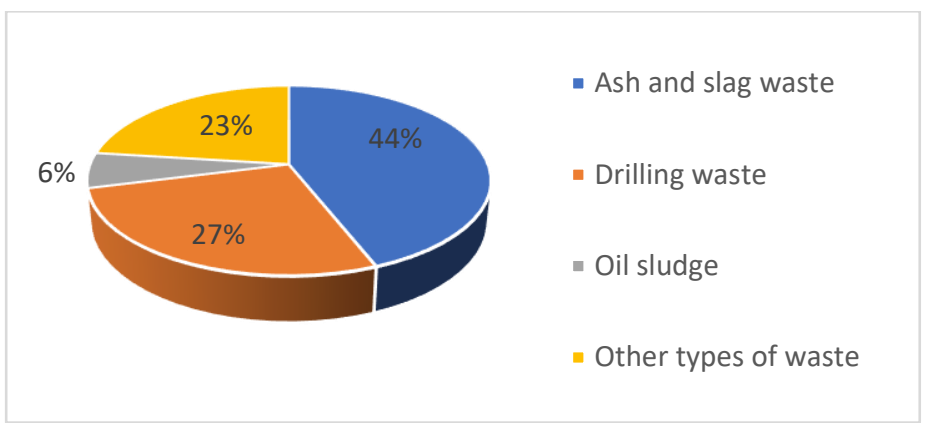

Fig. 6. Waste structure of Gazprom Group companies by type in $2019, \%$.

The main share in the waste structure falls on ash and slag wastes $(44 \%)$, which are accompanied in the activities of Gazprom, which are solid products of coal combustion generated at thermal power plants.

In 2019, PJSC Gazprom commissioned 10 waste disposal and disposal facilities with a total capacity of 93.96 thousand tons per year, as well as a landfill for recycling and disposal of household waste with a capacity of 0.23 thousand tons per year by OJSC "Tomskgazprom" [10].

\subsection{Use of associated petroleum gas}

Taking into account the transition of the economy to a low-carbon and energy-efficient development path, PJSC Gazprom is taking measures to reduce the flaring of associated petroleum gas in order to reduce emissions of pollutants and greenhouse gases.

When implementing investment projects for the use of associated petroleum gas at the fields of the Gazprom Group, the target reference point for the use of associated petroleum gas is at least $95 \%$.

In 2019, the indicator of useful use of associated petroleum gas at PJSC Gazprom amounted to $98.5 \%$ [10].

\subsection{Environmental exposure warnings}

\subsubsection{Environmental assessment of projects}

PJSC Gazprom conducts environmental assessment of investment projects at all stages of the life cycle, taking into account the requirements of Russian and international legislation, as well as corporate expertise of design materials.

As part of the expert review, the documents are assessed for compliance with PJSC Gazprom's regulatory and methodological documents in the field of environmental protection.

In 2019, 394 sets of pre-design and project documentation were considered as part of a corporate environmental review of facilities for construction, reconstruction, construction, modernization and technical re-equipment [10].

This measure is aimed at improving the quality of documentation in terms of taking timely measures to reduce environmental risks during project implementation. 


\subsubsection{Environmental risk insurance}

PJSC Gazprom and JSC SOGAZ have a liability insurance contract for damage to the environment (environmental risks), life, health and property of third parties in relation to the activities of PJSC Gazprom.

Environmental insurance covers these risks in the course of onshore and offshore exploration and drilling operations, production, transportation, processing, storage of hydrocarbons and other operations.

In 2019, payments by SOGAZ JSC amounted to 243.38 million rubles, of which the previous periods amounted to 224.39 million rubles [10].

\subsubsection{Industrial environmental control and monitoring}

PJSC Gazprom carries out industrial environmental control at production facilities. It is aimed at meeting the requirements of environmental legislation, compliance with environmental standards, ensuring the rational use of natural resources and minimizing the impact on the environment.

There is also an environmental inspectorate that monitors the compliance of subsidiaries with environmental legislation and conducts internal audits of the environmental management system.

In 2019, 424 inspections of this kind were carried out, based on the results, recommendations were made to improve environmental protection activities, the rate of elimination of inconsistencies within the specified period was $98 \%$ [10].

In the process of developing investment projects, when assessing the impact on the environment, vulnerable ecosystems are identified, which provide for measures to prevent disruption of the natural balance during the construction and operation of facilities. In addition, industrial environmental monitoring of environmental parameters is carried out, including the state of objects of flora and fauna.

Industrial environmental monitoring is carried out through the operation of stationary and mobile environmental laboratories, meteorological posts, automated control posts, observation wells. This approach makes it possible to control 3B emissions into the atmospheric air, noise impact, radiation background, quality of surface and ground waters, the state of the geological environment, waste and wastewater.

For the period 2015-2019 Gazprom Group companies allocated 13.3 billion rubles to ensure industrial environmental monitoring and control (Fig. 7).

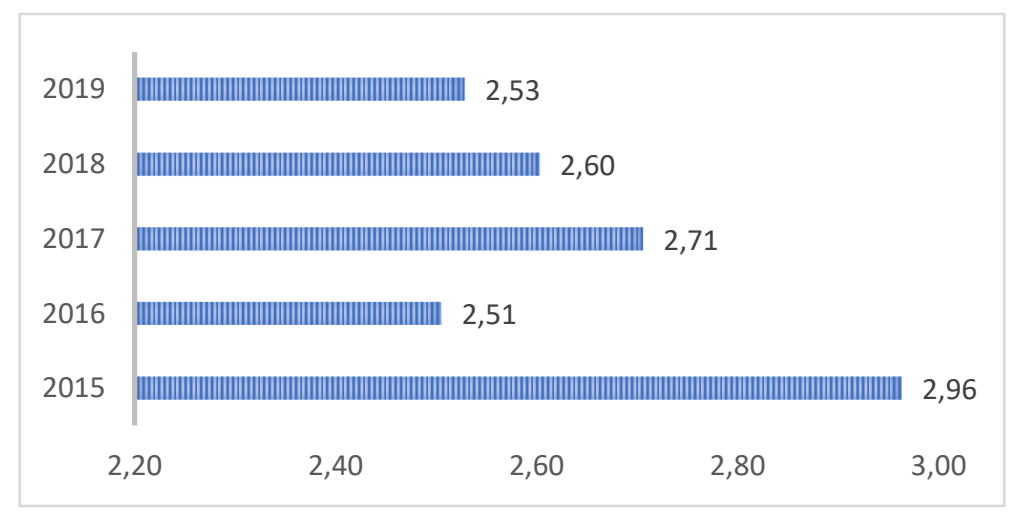

Fig. 7. Expenses by Gazprom Group companies for industrial environmental monitoring and control for 2015-2019, billion rubles. 
The established industrial environmental monitoring system allows you to promptly receive all the necessary information about the environmental status at PJSC Gazprom's facilities, conduct a timely engineering analysis of the current environmental situation, plan environmental protection measures, exercise control over them, and make effective management decisions in the field of environmental protection.

\subsubsection{State environmental supervision}

In 2019, state supervisory authorities conducted 628 inspections of compliance with environmental requirements during the operation of PJSC Gazprom's facilities, of which 388 inspections did not reveal violations $(62 \%)$.

The rest of the inspections revealed 527 violations, of which 284 violations (54\%) were eliminated within the prescribed period. In 2019, Gazprom Group companies paid fines totaling 14.63 million rubles, and 119.07 million rubles were paid as part of compensation for environmental damage [10].

\section{Conclusion}

In order to assess the impact on the environment, it is proposed to use the proposed methodology based on a semi-quantitative assessment with the assignment of scores for indicators taking into account the gradation and category of impact significance, as well as to calculate a comprehensive (integral) assessment of the impact on individual components of the environment depending on various sources of impact.

The priority areas of OVOS-based financing for PJSC Gazprom are the protection of atmospheric air, as well as the protection and rational use of water resources $(>80 \%$ of the total funding). At the same time, investments in fixed assets in 2019 aimed at environmental protection and rational use of natural resources decreased by 15 billion rubles compared to 2017. This is due to the completion of large investment projects PJSC Gazprom.

When implementing projects of PJSC Gazprom, there is a negative impact on the environment, including in the course of production activities of the facilities, a large amount of water is used and wastewater is discharged into surface water bodies, as well as during geological exploration and construction work, a negative impact is exerted on vegetation and soil cover.

Therefore, in the structure of costs, the largest share falls on the collection and treatment of wastewater, as well as protection and rehabilitation of land $(>60 \%$ of the total cost). Evaluation of the cost effectiveness of PJSC Gazprom for data is needed for the period 20152019 are expressed in a reduction in water consumption for industrial needs by $11 \%$ and water intake from natural sources by $17 \%$, as well as reclaimed $65 \%$ of the total volume of disturbed lands.

Targets reflected in the integrated environmental program PJSC Gazprom for 2020-2024 require additional indicators for a comprehensive EIA. These can be qualitative and quantitative indicators of impact assessment (intensity, specific power, frequency of time, duration, spatial boundaries, etc.).

\section{References}

1. Environmental policy of OAO Gazprom (approved by Resolution of the Management Board No. 21 dated May 25, 2015).

2. M.A. Arystanbek, Scientific news, 4, 121-128 (2019) 
3. O.V. Kudryavtseva, T.N. Ledashcheva, V.E. Pinaev, Methodology and practice of environmental impact assessment. Project documentation: Textbook. allowance (M.: Moscow State University named after M.V. Lomonosov, Faculty of Economics, Moscow, 2016)

4. T.N. Ledashcheva, V.I. Pinaev, Environmental support of projects in Russia - modern practice (World of Science, Moscow, 2019).

5. A.N. Matveev, Environmental impact assessment: textbook. allowance (Irkut Publishing House. state University, Irkutsk, 2007)

6. V.G. Parfenov, Yu.I. Sivkov, A.S. Nikiforov, Assessment of the environmental impact of oil and gas facilities: Textbook. allowance (Tyumen Industrial University Publishing House, Tyumen, 2016)

7. S.G.Tyaglov, N.N.Kiseleva, V.A. Timchenko Modern aspects of the development of the "Green Economy" in the Russian Federation (monograph). (Fund for Innovation and Economic Technologies "Assistance - XXI century", Rostov-on-Don, 2017)

8. O.I. Sharno, Law and State: Theory and Practice, 12, 135-138, (2020)

9. V.N. Ekzaryan, M.V. Bufetova, Environmental Impact Assessment: Textbook. allowance (Scientific Consultant LLC, Moscow, 2018)

10. Environmental report of PJSC Gazprom for 2019 